\title{
Nova reforma slovenske dohodnine
}

\author{
UDK: 33.22:65.011.8 \\ Mitja Čok \\ Univerza v Ljubljani, Ekonomska fakulteta \\ mitja.cok@ef.uni-lj.si
}

\begin{abstract}
IZVLEČEK
Strokovna skupina za pregled in pripravo zakonodaje na davčnem področju, ki jo je imenovala vlada Republike Slovenije, je v okviru svojega dela pripravila tudi predloge za spremembo zakona o dohodnini. Velik del predlaganih sprememb je bil konec leta 2005 v obliki zakona tudi sprejet. Bistvo predlaganih sprememb je $v$ odpravi nekaterih nejasnosti, poenostavitvi obdavčitve posameznih vrst dohodkov ter $v$ uvedbi cedularnega pristopa pri obdavčitvi večine dohodkov iz premoženja ter dobička iz kapitala. Nadaljnje spremembe dohodnine so mogoče v obstoječi smeri (t.j. s popravki obstoječega zakona), manj verjetna pa se zdi radikalna reforma dohodnine $v$ skladu s konceptom $t . i$. enotne davčne stopnje.
\end{abstract}

Ključne besede: javne finance, davki, dohodnina, davčne reforme

\section{Uvod}

Republika Slovenija je že $\vee$ začetku 90. let sprejela večji del osnovne davčne zakonodaje $v$ obliki, ki je primerljiva $z$ ureditvijo $v$ zahodnoevropskih državah. Pomembnejša izjema je bil zgolj davek na dodano vrednost, ki ga je Slovenija uvedla leta 1999. Spremenjene družbeno-ekonomske in mednarodne razmere konec prejšnjega desetletja so narekovale tudi spremembe $v$ nekaterih davčnih zakonih in tako je $v$ letu 2004 slovenski parlament sprejel nove zakone o davčnem postopku, davku od dohodkov pravnih oseb in dohodnini (ZDoh-1), ki so začeli veljati s 1.1.2005. Že $v$ fazi sprejemanja teh zakonov, še bolj pa ob začetku njihovega izvajanja je bilo jasno, da nekatere rešitve, ki so v njih zapisane, niso najboljše. S sklepom vlade je bila tako januarja 2005 ustanovljena Strokovna skupina za pregled in pripravo zakonodaje na davčnem področju, katere mandat je bil priprava predlogov za odpravo največjih neskladij v teh treh zakonih. Skupina je do junija 2005 pripravila prve predloge sprememb, na podlagi katerih je Ministrstvo za finance pripravilo novele zakonov, ki jih je 
Mitja Čok

Nova reforma slovenske dohodnine

parlament sprejel $\vee$ decembru 2005 ter so v veljavi od januarja 2006 naprej. Pri dohodnini so spremembe zajete $\vee$ ZDoh-1D' ${ }^{\mathbf{1}}$. Vlada Republike Slovenije je poleg prej omenjene skupine ustanovila tudi Odbor za reforme, ki je septembra 2005 javnosti predstavil sveženj predlogov reform za vrsto področij, vključno z davčnim. Jedro davčnih sprememb se skriva $\vee$ predlogu enotne davčne stopnje (EDS), katere izpeljava bi pomenila novo, do sedaj najbolj korenito reformo ne zgolj dohodnine, ampak tudi vrste drugih davkov ter socialnih transferjev, saj bi spremenila marsikatero razmerje, ki trenutno velja v slovenski družbi.

$\checkmark$ nadaljevanju je podan prikaz najpomembnejših sprememb pri zakonu o dohodnini, ter vprašanj, ki se pojavljajo ob predlogu enotne davčne stopnje $z$ vidika dohodnine.

\section{Spremembe pri dohodnini}

Strokovna skupina je pri pripravi predlogov za spremembe dohodnine upoštevala težave in pripombe, ki so jih imeli s "starim « zakonom, ki je začel veljati z začetkom leta 2005, tako davčni zavezanci kot davčna uprava. Uzakonjene spremembe $\vee$ ZDoh-1D so tako $\vee$ veliki meri enake predlogom skupine, $v$ nekaterih primerih pa je parlament sprejel rešitve, ki jih skupina ni predlagala ali pa so bile bistveno drugačne.

\subsection{Cedularna obdavčitev za najemnine, obresti in divi- dende ter za dobičke iz kapitala}

Vsebinsko najpomembnejša sprememba pri dohodnini vsebuje izvzem nekaterih oblik dohodkov iz progresivne obdavčitve ter njihovo posebno obdavčenje na cedularni osnovi, t.j. z eno samo proporcionalno stopnjo. Mednarodna praksa kaže, da je kapital izredno mobilen produkcijski faktor, zato imajo države vrsto mehanizmov, s katerimi ga skušajo zadržati. Ni na primer naključno vztrajanje nekaterih držav članic EU pri tajnosti davčnih depozitov. Kljub sprejeti EU direktivi št. 2003/48/EC o medsebojni izmenjavi informacij o bančnih depozitih so Avstrija, Belgija, Luksemburg $\vee$ pogajanjih dosegle prehodno obdobje, $v$ katerem še nekaj let drugim državam ne bodo poročale imen tujih varčevalcev, ki imajo vloge $v$ njihovih bankah (Čok in Košak, 2004, Lindstrom-Ihre et all, 2003) spomnimo pa se lahko tudi konca leta 2004, ko je prihajajoča obdavčitev pretežnih lastniških deležev povzročila umik kapitala iz Slovenije $v$ države $z$ nižjimi davki. Eno od izhodišč skupine je bila zato uvedba

1 Zakon o spremembah in dopolnitvah zakona o dohodnini (ZDoh-1D), Uradni list RS 115/04. 
predloga za cedularno obdavčitev večine dohodkov iz premoženja ter za dobičke iz kapitala, saj podobno rešitev pozna vrsta zahodnoevropskih držav. Po predlogu skupine so tako najemnine, obresti, dividende ter dobički iz kapitala izvzeti iz integralne obdavčitve s progresivno lestvico ter obdavčeni posebej, zgolj z eno samo, $20 \%$ davčno stopnjo. Ti dohodki se torej ne vštevajo $v$ osnovo za integralno dohodnino, kar pomeni, da se pri njihovi obdavčitvi tudi ne upoštevajo davčne olajšave. Po predlogu skupine so kapitalski dobički, ki izvirajo iz pretežnega lastniškega deleža, izenačeni z drugimi kapitalskimi dobički (t.j. niso več posebej definirani), poleg tega pa se investicijski kuponi vzajemnih skladov izenačijo z drugimi vrstami vrednostnih papirjev. Pomemben del predloga je tudi $\vee$ tem, da pri obdavčitvi kapitalskih dobičkov ni več časovnih rokov definiranih na enak način kot $\vee$ Zdoh-1, se pa stopnja davka vsakih pet let zniža za 1/4, kar pomeni, da po dvajsetih letih kapitalski dobički ne bi bili več obdavčeni. Izjema so zgolj rezidenčna stanovanja, kjer je enako kot $\vee$ Zdoh-1 kapitalski dobiček obdavčen zgolj prva tri leta. Predlog tudi vsebuje določbo, naj bi bile obresti iz hranilnih bančnih vlog obdavčene šele nad zneskom 100.000 tolarjev. Ob trenutni višini obrestnih mer bi iz obdavčitve obresti tako izpadla večina zavezancev, saj povprečna slovenska bančna vloga na letni ravni prinaša manj kot 100.000 tolarjev obresti. Pri obrestih je bilo tudi predlagano prehodno obdobje za leti 2006 in 2007, v katerem naj bi bile obresti obdavčene s $15 \%$ in ne z $20 \%$ stopnjo, s čimer bi preprečili odliv prihrankov iz Slovenije. Razlog je $v$ začetku delovanja prej omenjene direktive št. 2003/48/EC, ki določa izmenjavo informacij o obrestih v EU, saj bodo Avstrija, Belgija in Luksemburg $\checkmark$ tem obdobju obresti nerezidentov obdavčevale zgolj s 15\% stopnjo, imen bančnih komitentov pa ne bodo sporočale matičnim državam.

Uzakonjena sprememba zakona o dohodnini (Zdoh-1D) v veliki meri sledi predlogu skupine, sprejeta cedularna stopnja je enaka predlagani (20\%), pri čemer se le-ta za kapitalske dobičke znižuje za 1/4 za vsakih dopolnjenih pet let lastništva kapitala, kar je enako predlogu. Iz cedularne obdavčitve pa so izpadle najemnine, ki bodo še naprej obdavčene s progresivno lestvico, pri čemer je treba dodati, da je Ministrstvo za finance povišalo normirane stroške pri najemninah iz $20 \%$ na $40 \%$. Nekoliko drugačna od predlagane je tudi obdavčitev obresti za denarne depozite pri bankah in hranilnicah. Sprejeta rešitev iz obdavčitve izvzema te obresti $\vee$ višini 300.000 tolarjev v letu 2006 ter $\vee$ višini 150.000 tolarjev $\vee$ letu 2007, v nadaljnjih letih pa te oprostitve ni več. $\vee$ letih 2006 in 2007 bodo, enako kot je bilo predlagano, te obresti obdavčene z 15\% in ne z $20 \%$ davčno stopnjo.

Uzakonjene spremembe tudi pomenijo, da je Republika Slovenija že uvedla "enotno davčno stopnjo " na zelo majhnem segmentu dohodninske osnove (obresti, kapitalski dobički in dividende znašajo le nekaj odstotkov celotnega 
dohodka, ki ga zajema dohodnina), kar je koristno tudi z vidika nadaljnjih razprav in izračunov celovitega sistema EDS. S sprejeto cedularnostjo bomo namreč pridobili prve izkušnje o tem, kako se bodo zavezanci odzvali na proporcionalno obdavčitev in kakšni bodo učinki na državni proračun. Sprejeta rešitev največ prinese premožnejšemu segmentu zavezancev, ki razpolagajo $v$ večjim delom kapitala, ki prinaša dohodke, predvsem pa je pomembna za podjetniški sektor. Uzakonjena $20 \%$ obdavčitev dividend je spodbuda lastnikom podjetij, ter je skupaj s postopno odpravo davka na izplačane plače (le-ta bo $v$ celoti odpravljen do leta 2009) ${ }^{2}$, verjetno največ, kar lahko država kratkoročno "podari« podjetniškemu sektorju, ne da bi ogrozila stabilnost javnih financ.

Strokovna skupina je tudi predlagala, naj bi se dohodnina ne plačevala od zamudnih obresti, ki jih s sodbo določi sodišče, ter od obresti iz naslova denacionalizacijskih obveznic, saj gre za dohodke, ki izhajajo iz dejanj tretjih oseb na katere zavezanec ni imel neposrednega vpliva, da bi jih dejansko ustvaril. Uzakonjena rešitev iz obdavčitve izvzema zamudne obresti, izplačane na podlagi sodne odločbe $v$ skladu $s$ predlogom, medtem ko $v$ osnovo za dohodnino vključuje $50 \%$ obresti od denacionalizacijskih obveznic.

\subsection{Vprašanje razmejitve odvisnega in neodvisnega delovnega razmerja}

Novo uvedeni kriteriji v "starem « zakonu o dohodnini (ZDoh-1), ki razmejujejo odvisno oz. neodvisno delovno razmerje, povzročajo težave tako zavezancem kot davčni upravi. Obstoječa rešitev je namreč kljub svoji ekonomski logičnosti v praksi težko izvedljiva ter zavezancem ne zagotavlja pravne varnosti. Glede na velikost Slovenije bo do vzpostavitve ustrezne davčne in sodne prakse treba še dolgo počakati, zato naj bi se do priprave bolj transparentne zakonske dikcije po predlogu skupine črtali kriteriji iz 18. člena, ki razmejujejo odvisno in neodvisno delovno razmerje. Skupaj z ustreznimi drugimi popravki bi se tako vzpostavilo podobno stanje kot je veljalo pred 1.1.2005, t.j. status delovnega razmerja naj bi bil odvisen od formalnega statusa naročnika in izvajalca dela (delodajalca in delojemalca). Črtanje določb 18. člena zakona o dohodnini pa tudi pomeni, da bi bilo treba s pravilnikom o izvajanju zakona o davku na dodano vrednost natančno urediti status davčnih zavezancev za davek na dodano vrednost. Ministrstvo za finance predloga skupine ni sprejelo, tako da ostajajo zadevni členi iz ZDoh-1 še naprej v veljavi.

2 Zakon o spremembah in dopolnitvah Zakona o davku na izplačane plače (ZDIP-D), Uradni list RS $108 / 05$. 


\subsection{Poenostavitve za samostojne podjetnike}

Po predlogu strokovne skupine naj bi bila omogočena "dokapitalizacija" podjetja zasebnika tudi po začetku opravljanja dejavnosti in ne zgolj ob začetku poslovanja, kot je določal ZDoh-1. Po predlogu naj bi bili tudi spremenjeni pogoji, pod katerimi lahko zavezanec-zasebnik prenaša dejavnost na ožje družinske člane, saj sedanji zakon dopušča neobdavčen prenos zgolj pod relativno ostrimi pogoji, npr. $v$ primeru upokojitve ali smrti zavezanca. Ministrstvo za finance je del teh predlogov sprejelo, enako kot je sprejelo tudi predlog za povišanje praga dohodka pri tistih zasebnikih, ki davčno osnovo lahko določajo z normiranimi odhodki. V primerjavi z ZDoh-1, kjer je bil prag letnih prihodkov postavljen pri 3,9 milijona tolarjev letnega dohodka, je $\vee$ ZDoh-1D prag dvignjen na 6 milijonov tolarjev. Z dvigom praga, od katerega se davčna osnova določa z normiranimi odhodki, se bo $v$ to kategorijo uvrstilo več zasebnikov, kar zanje pomeni poenostavitev vodenja knjigovodstva, izkušnje pa tudi kažejo, da takšni zavezanci plačujejo več davka. Ministrstvo za finance je poleg tega tudi povišalo normirane odhodke na $70 \%$ za tiste zavezance, ki opravljajo kmetijsko in dopolnilno dejavnost na kmetiji, ter pri dejavnosti domače in umetne obrti ter občasnega oddajanja sob.

Strokovna skupina je predlagala tudi nov pristop k obdavčenju čebelarjev. Po predlogu naj bi se čebelarjem, ki imajo manjše število panjev (npr. do 40), letna davčna osnova lahko določila $\vee$ pavšalnem znesku na panj. $S$ tem bi čebelarjem poenostavili davčni obračun, pristop pa bi se kasneje lahko uporabil tudi za druge manjše zavezance s področja kmetijske dejavnosti, ki niso obdavčeni na osnovi katastrskega dohodka. Ministrstvo za finance tega predloga ni sprejelo.

\subsection{Bonitete in vprašanje detaširanih delavcev}

ZDoh-1 je kot boniteto določal tudi uporabo prenosnega telefona in parkirišča, kar je povzročalo zavezancem veliko administriranja. Predlog skupine je bil, naj se to ne upošteva kot boniteta, saj gre za sredstva, ki so potrebna za normalno poslovanje gospodarstva. Ministrstvo za finance je predlog skupine sprejelo, $\checkmark$ ZDoh-1D se tako uporaba računalniške in telekomunikacijske opreme ter parkirnega prostora, ki ga zagotovi delodajalec, ne šteje več kot boniteta. Skupina je tudi predlagala poenostavitev obračuna bonitete za uporabo osebnega avtomobila v zasebne namene, na način, ko višina bonitete ne bi bila več odvisna od števila prevoženih kilometrov, kar bi poenostavilo vodenje evidenc. Ta predlog ni bil sprejet. 
Mitja Čok

Nova reforma slovenske dohodnine

Dohodki detaširanih delavcev (t.j. delavcev napotenih na delo $v$ tujino) so bili v ZDoh-1 izenačeni z dohodki "domačih « delavcev, ter v skladu z načelom svetovnega dohodka obdavčeni $\vee$ Sloveniji. $\vee$ praksi je to pomenilo efektivno višjo obdavčitev slovenskih delavcev $\vee$ primerjavi s tujimi $\vee$ državah, kjer so ti delavci na začasnem delu. Zato so bile $v$ Doh-2 uvedene spremembe, ki se nanašajo na določitev davčne osnove javnih uslužbencev in mornarjev. Pri javnih uslužbencih in funkcionarjih napotenih na delo $v$ tujino bo davčna osnova enaka dohodkom, ki bi jih prejemali za enaka dela v Sloveniji, pri zaposlenih na trgovskih ladjah dolge plovbe pa bo davčna osnova $70 \%$ prejetega dohodka. $S$ to spremembo se je tako izboljšal položaj zgolj dveh kategorij detaširanih delavcev, pri drugih je vprašanje ostalo odprto.

\subsection{Izenačitev pokojnin iz tretjega stebra z življenjskim zavarovanjem}

$\checkmark$ ZDoh-1 ni bilo spodbud za prostovoljno dodatno pokojninsko zavarovanje, za katerega zavezanci ne morejo uveljavljati davčnih olajšav (za zavarovanje $\checkmark$ t.i. tretjem stebru), saj premije za takšno zavarovanje niso bile oproščene dohodnine, donosi od tega zavarovanja pa so bili v celoti obdavčeni. Po predlogu skupine, ki ga je Ministrstvo za finance sprejelo, se v ZDoh-1D takšno zavarovanje izenači z življenjskim, tako da bodo njegovi donosi oz. pokojnina, ki jih bo zavezanec prejemal po določenem časovnem obdobju, neobdavčeni. Namen te spremembe je spodbuditi dodatno pokojninsko zavarovanje.

\subsection{Samoobdavčitev in letna dohodnina}

$\checkmark$ skladu s predlogom skupine naj bi imeli zavezanci možnost, da si lahko sami izračunajo letno dohodnino. S tem bi se Slovenija približala razvitim državam, ki tovrstni institut že imajo, takšna rešitev pa bi do določene mere pomenila tudi razbremenitev davčne uprave.

Za Slovenijo je tudi značilna visoka skupna obdavčitev plač, saj spadamo med države z visokimi stopnjami prispevkov za socialno varnost, pri čemer je slovenska posebnost tudi $v$ tem, da osnova za plačevanje prispevkov navzgor ni omejena, medtem ko so navzgor omejene pravice, ki izvirajo iz socialnega zavarovanja (pokojnine, porodniška nadomestila, itd.). Po podatkih EU ima 50\% ali višjo stopnjo dohodnine poleg Slovenije samo še pet držav v skupnosti, med njimi nobena od novih članic (European Commision, 2004). V okviru sprememb je skupina zato predlagala tudi drugačno dohodninsko lestvico, z manj razredi ter najvišjo mejno stopnjo, ki bil bila pod $50 \%$. Seveda pa bi bila dokončna oblika lestvice odvisna tako od politične odločitve (katere sloje prebivalstva razbremeniti 
in katere obremeniti) kot od proračunske vzdržnosti posameznih inačic lestvice. Nobeden od teh dveh predlogov (t.j. samoobdavčitev ter drugačna lestvica) ni bil sprejet.

\section{Nadaljnje reforme dohodnine?}

Kljub temu, da so spremembe pri dohodnini ter drugih davčnih zakonih (davku od dohodkov pravnih oseb, davčnem postopku in davku na izplačane plače), ki so bile sprejete konec leta 2005, pomemben korak $v$ razbremenitvi gospodarstva tako z vidika manjšega obsega administriranja kot dejanskega znižanja davkov, pa so ostale $v$ senci javne diskusije o EDS.

\subsection{Kaj je enotna davčna stopnja?}

Pri EDS gre za koncept, ki je že dolgo poznan; R. Hall in A. Rabushka, ekonomista s Stanfordske univerze $\vee$ ZDA, sta npr. v 80. letih prejšnjega stoletja (Hall in Rabushka, 1983) predlagala posebno obliko neposrednega davka na potrošnjo (expenditure tax), ki bi zamenjal siceršnjo dohodnino in davek od dohodkov (dobičkov) pravnih oseb. V ZDA so ga poimenovali "flat-tax". Pri tej obliki davka bi obdavčitev z eno davčno stopnjo potekala tako na ravni podjetja kot posameznika. Osnova za davek na ravni podjetja bi bila enaka, kot je osnova za davek na dodano vrednost (DDV) s tem, da bi se od nje dodatno odšteli tudi stroški dela. Na ravni posameznika pa bi bila davčna osnova enaka dohodkom od dela (plači), ob upoštevanju fiksne davčne olajšave. $V$ praksi ni tega predloga uvedla nobena država, obstaja pa vrsta davčnih sistemov, kjer je ena sama stopnja pri dohodnini zamenjala sicer prevladujočo progresivno stopničasto obdavčitev. $\vee$ strokovni terminologiji zato izraz "enotna davčna stopnja» (flat-tax) predvsem označuje dohodnino z eno samo stopnjo ter relativno enostavnim sistemom olajšav. $V$ takšni ali drugačni različici so jo do sedaj uvedle Litva (1994), Latvija (1994), Estonija (1996), Rusija (2001), Srbija (2003), Slovaška (2004), Gruzija (2005), med državami s seznama pa najdemo tudi Hong Kong, Jersey, itd.

$\checkmark$ Sloveniji nam pojem EDS običajno v spomin prikliče Slovaško, kjer imajo od leta 2004 naprej pri dohodnini eno samo stopnjo $v$ višini 19\%, poleg tega pa je enaka in zgolj ena $19 \%$ stopnja tudi pri DDV, z $19 \%$ pa so obdavčeni tudi dohodki pravnih oseb. Na Slovaškem imajo torej trije vsebinsko različni davki enako stopnjo, kar pa ne pomeni, da to velja za vse države iz prej omenjene skupine. Latvija, ki ima 25\% "enotno stopnjo « pri dohodnini, ima pri DDV dve stopnji $(18 \%$ in $5 \%)$, medtem ko je stopnja pri davku od dohodkov pravnih 
oseb $15 \%$. Tudi v Rusiji se $13 \%$ "enotna stopnja " pri dohodnini razlikuje od stopenj DDV (18\% in 10\%) in stopnje davka od dohodkov pravnih oseb (24\%), itd. (International Bureau of Fiscal Documentation, 2005).

\subsection{Enotna davčna stopnja in slovenska dohodnina}

Ob predpostavki, da bi tudi Slovenija uvedla slovaško različico EDS, bi torej pri treh davkih: dohodnini, davku od dohodkov pravnih oseb in DDV imeli enako davčno stopnjo, najbrž v višini okrog $20 \%$. Pri tem pa se odpira vrsta vprašanj, v nadaljevanju si poglejmo zgolj tista, ki so povezana z dohodnino.

Podatki o distribuciji davčnega bremena $\vee$ Sloveniji v skladu z ZDoh-1, ki je bil $v$ veljavi $v$ letu 2005, niso na razpolago, saj bo dohodnina po njem odmerjena šele $v$ letu 2006. Kljub temu, da se ta zakon od predhodnega (ki je veljal do konca leta 2004) razlikuje $v$ mnogih elementih, pa spremembe $v$ širinah razredov, olajšavah in mejnih stopnjah niso tako zelo velike, da bi se razmerja med relativno davčno obremenitvijo zavezancev bistveno spremenila in tudi spremembe zajete $v$ ZDoh-1D niso tako velike, da bi na ta razmerja bistveno vplivale. Za ilustracijo zato lahko uporabimo podatke iz leta 2002, ko je povprečna stopnja dohodnine, izražena kot razmerje med dohodnino in davčno osnovo, od katere je bila odmerjena, za vseh 1.154 .000 zavezancev znašala 19,6\% (Ministrstvo za finance, 2004). Med vsemi zavezanci pa je imelo nižjo povprečno stopnjo kot $19,6 \%$ kar 1.041 .000 oz. $90 \%$ posameznikov. Z drugimi besedami, v Sloveniji je bilo zgolj 113.000 oz. 10\% davkoplačevalcev, ki so plačali dohodnino po povprečnih stopnjah nad $19,6 \%$. Uvedba ene same stopnje dohodnine $v$ višini okrog $20 \%$ bi bila ob nespremenjenih olajšavah torej proračunsko nevtralna (državi bi prinesla enak obseg davka), povzročila pa bi redistribucijo davčnega bremena - $v$ korist premožnejših in na škodo revnejših.

Višanje obsega olajšav ali uvedba nižje "enotne stopnje« kot je $20 \%$, s čimer bi dosegli, da je manj zavezancev "na slabšem «, pa nujno vodi v manjši obseg pobrane dohodnine. Leta 2004 je dohodnina dosegla 382,5 milijarde tolarjev pri čemer ne smemo pozabiti, da se deli v razmerju 65:35 med Republiko Slovenijo in občine. Manjši obseg pobrane dohodnine bi $v$ tem primeru verjetno pomenil tudi dodatne zahteve občin za sredstva iz državnega proračuna, saj je dohodnina njihov najpomembnejši vir. Med 311,0 milijardami občinskih prihodkov leta 2004 jih je kar 133,9 milijard (43\%) izviralo iz dohodnine, transferji občinam iz državnega proračuna pa so npr. dosegali 50 milijard.

Teoretično obstaja še možnost, da bi se neto plače "zamrznile", na tej osnovi pa bi se ob upoštevanju ene same stopnje dohodnine določile "nove« bruto plače. Takšen pristop je ne samo tehnično zahteven (spremeniti bi bilo treba vse splošne, panožne in individualne pogodbe, pri čemer bi bilo tudi 
težko doseči, da bi bile "nove " bruto plače natanko takšne, kot bi si želeli), ampak posega tudi $\vee$ sistem prispevkov za socialno varnost, ki temeljijo na obstoječih bruto plačah. Sedanja stopnja prispevkov v višini 38,2\% (16,1\% plačajo delodajalci, $22,1 \%$ pa delojemalci) ter obstoječa osnova zanje - obstoječe bruto plače - prinesejo 899,4 milijard pobranih prispevkov za socialno varnost (leta 2004). To zadošča, da Zavod za zdravstveno zavarovanje Slovenije (ZZZS) komajda posluje s kolikor toliko izravnano bilanco (v letu 2004 je imel 9,7 milijard primanjkljaja), medtem ko Zavod za pokojninsko in invalidsko zavarovanje (ZPIZ) brez državne pomoči pokrije zgolj dve tretjini svojih potreb (med 833,2 milijardami prihodkov ZPIZ leta 2004 je bilo 244,5 milijard, ki jih je v ZPIZ nakazal državni proračun). Skratka, nova višina bruto plač bi zelo verjetno zahtevala tudi določitev novih stopenj prispevkov za socialno varnost, sicer bi se prizadelo poslovanje pokojninske in zdravstvene blagajne. Takšna razbremenitev stroškov dela z "enotno stopnjo " dohodnine in morebitnimi spremembami bruto plač (ter posledično stopnjami prispevkov za socialno varnost) bi bila zato izredno zapletena in precej negotova.

Zgolj zamenjava progresivne lestvice z eno samo stopnjo tudi ne pomeni poenostavitve sistema dohodnine (ali kateregakoli drugega davka), saj so vzroki zapletenosti povsem drugačni. Skrivajo se $v$ nejasnih definicijah davčnih osnov (npr. $v$ razlikovanju odvisnega in neodvisnega delovnega razmerja ali razmejevanju davčno priznanih in nepriznanih odhodkov); v obsežnem in nepotrebnem administriranju z majhnimi proračunskimi učinki (npr. obračun bonitet za uporabo prenosnega telefona in parkirišča, kar je bilo z ZDoh-1D nedavno odpravljeno), $v$ zapletenem davčnem postopku, itd. Vse te pomanjkljivosti je mogoče reševati zgolj z vsebinskimi popravki davčne zakonodaje in nikakor ne s spreminjanjem davčnih stopenj. Sama enostavnost davčnega sistema tudi ne more biti osnovni cilj reform, saj se vseh elementov preprosto ne da poenostaviti, ne da bi tvegali nove nejasnosti in dvoumnosti. Tudi odprava večine davčnih olajšav in posebnosti, ki bi vse zavezance postavila $v$ enak začetni položaj na trgu, je dvorezna, saj državi jemlje pomemben politični vzvod - fiskalni instrumentarij na strani prihodkov. Obstoječe davčne olajšave in posebnosti, ki so vtkane $v$ sistem, so tudi orodje, $s$ katerim se podpira in izvaja vrsta politik (demografska, kulturna, kmetijska, itd.). Slovenska država bo z evrom de facto izgubila monetarno politiko in z uvedbo sistema EDS bi izgubila še pomemben del fiskalne. Za doseganje želenih ciljev bi ji tako ostala samo še fiskalna politika na strani izdatkov, kar pomeni bistveno osiromašenje nabora ekonomskih vzvodov.

Če je namen EDS davčna razbremenitev dela, potem so na voljo mnogo bolj ustrezni pristopi. Pogled na agregatne davčne številke v letu 2004: prispevki za socialno varnost 899,4 milijard, dohodnina 382,5 milijard ter davek na 


\section{Mitja Čok}

\section{Nova reforma slovenske dohodnine}

izplačane plače 113,2 milijard (Ministrstvo za finance, 2005), nam pokaže, da so jedro problema visoke davčne obremenitve dela prispevki za socialno varnost, natančneje - obstoječa ureditev, ki ne vsebuje praga, od katerega naprej se prispevki ne bi plačevali. Slovenija je ena redkih držav, kjer osnova ni omejena in prispevki se plačujejo ne glede na njeno višino (bruto plačo), medtem ko so pravice, ki izhajajo iz socialnega zavarovanja, navzgor omejene (pokojnine, nadomestila, itd.). Poleg že sprejete odprave davka na izplačane plače bi bila uvedba praga pri prispevkih torej ukrep, ki bi najbolj spodbudil zaposlovanje visoko kvalificiranih delavcev (ki so najbolj produktivno jedro gospodarstva). Tudi če zanemarimo posledice uvedbe EDS pri drugih davkih (DDV, davek od dohodkov pravnih oseb) na konkurenčni položaj vrste gospodarskih panog in dohodkovni položaj znatnega dela prebivalstva, lahko zaključimo, da je že z vidika dohodnine njena uvedba zapletena, tako vsebinsko kot zakonodajnologistično.

\section{Zaključek}

V letu 2005 smo dobili vrsto popravkov dohodnine, med katerimi je najpomembnejši cedularna $20 \%$ obdavčitev dividend, obresti in kapitalskih dobičkov. S to ureditvijo se je Slovenija (zgolj) izenačila z vrsto zahodnih držav, ki dohodke iz kapitala pragmatično obdavčujejo izven progresivne dohodnine z relativno nizko proporcionalno stopnjo, jih s tem zadržijo pod svojo davčno jurisdikcijo in spodbujajo domačo ekonomsko aktivnost. Druge spremembe dohodnine $v$ veliki meri pomenijo poenostavitve tako za zavezance kot državno upravo, ter skupaj s spremembami davčne zakonodaje (odprava davka na izplačane plače, spremembe $v$ davčnem postopku in davku od dohodkov pravnih oseb) pomenijo korak $v$ smer razbremenitve gospodarstva, tako $z$ vidika manjšega obsega administriranja kot dejanskega znižanja davkov. Poleg teh sprememb je Slovenija dobila tudi predlog za uvedbo EDS, ki sproža vrsto vprašanj, tako pri dohodnini kot drugih vrstah davkov. Njena izpeljava bi bila vsebinsko in zakonodajno zelo zahtevna, zato menimo, da do njene realizacije ne bo prišlo. Za razbremenitev gospodarstva in izboljšanje davčnega sistema so na voljo drugi, mnogo bolj ustrezni mehanizmi, kar potrjujejo tudi nedavne spremembe davčne zakonodaje. $\vee$ tej smeri bi tudi morala potekati nadaljnja davčna reforma: $v$ poenostavljanju posameznih zakonov ter postopnemu zmanjševanju davkov, ki neposredno bremenijo slovensko gospodarstvo, skupaj z ustreznimi spremljajočimi ukrepi na družbeno nestresen način (krčenje javne porabe od enega proračunskega cikla do drugega, iskanje dodatnih virov 
z urejanjem manjših davkov, kot je davek na nepremičnine ali z dvigom stopenj DDV za odstotno točko ali dve), ki bi hkrati zagotavljali fiskalno stabilnost.

Mitja Čok je diplomiral na Ekonomski fakulteti Univerze v Ljubljani, leta 2003 je doktoriral na University of Bristol $v$ Veliki Britaniji. Na Ekonomski fakulteti predava predmete s področja javnih financ. V letu 2005 je bil član Strokovne skupine za pregled in pripravo zakonodaje na davčnem področju, pri delu Odbora za reforme ni sodeloval.

\section{Literatura in viri}

- Čok, M., Košak M. (2004): „Nova davčna zakonodaja in poslovanje bank v Sloveniji«, Dnevi slovenskih bančnikov (zbornik), Združenje bank Slovenije, Ljubljana, str. 55-76.

- European Commision (2004): "Structures of the taxation systems in the European Union, Data 1995-2002«, Directorate General Taxation and Customs Union, Luksemburg.

- Hall R., Rabushka, A. (1983): " Low Tax, Simple Tax, Flat tax", McGraw-Hill, New York.

- International Bureau of Fiscal Documentation (2005): „European Tax Handbook «, Amsterdam.

- Lindstrom-lhre L., Huygen W., Couzin R., Gonzalo J. L. (2003): „EU Finance ministers reach final agreement on tax package«, Journal of International Taxation, (9), št. 14, str. 9-10.

- Ministrstvo za finance Republike Slovenije (2004): "Osnovni podatki o odmeri dohodnine za leto 2002« (gradivo), Ljubljana.

- Ministrstvo za finance Republike Slovenije (2005): „Bilten javnih financ«, 2005, št.11, Ljubljana. 
Mitja Čok

Nova reforma slovenske dohodnine

\section{SUMMARY}

\section{New Reform of Slovenian Tax System}

In January 2005 a group of experts was appointed by the government of the Republic of Slovenia with the task to improve several tax codes including the personal income tax code. The group had prepared proposals of changes and some of them were accepted by the Ministry of Finance and passed the Parliament in December 2005. Regarding the personal income tax the most important change includes schedular taxation of interest, dividends and capital profits. Namely, these types of income are excluded from the comprehensive tax base, which is taxed according to the progressive schedule, and are rather taxed separately with a single $20 \%$ proportional tax rate. With this solution Slovenia has already effectively introduced a "flat-tax" on a minor share of personal income.

Ministry of Finance has also accepted several other proposals connected with simplified taxation of sole proprietor, regarding the increase of his capital and taxation of income in case of transferring his business to other persons. Changes in personal income tax code also include abolishment of taxation of some benefits in kind, tax relief for diplomats and sailors working abroad as well as new tax incentives for non-compulsory pension insurance. On the other hand the Ministry of Finance has not adopted proposals connected with the differentiation of income deriving from independent and dependent employments, proposals for individual self-assessment and a proposal for new tax schedule with only three tax brackets (instead of five).

In 2005 the government also established another group of experts who have proposed a comprehensive bunch of reforms for several fields of the economy. Among them is also a recommendation for a flat-tax system, which would include personal income tax, corporate income tax and value added tax. This system would be similar to the Slovakian one where all three taxes reveal the same tax rate. In the case of Slovenia, the single flax-rate would be $20 \%$. From the personal income tax point of view, the introduction of a single rate instead of a progressive tax schedule does not mean a great simplification of the system since its complexity depends mostly on the definition of tax base. Only one tax rate also carries a 
redistribution of tax burden (in favour of individuals with higher income) or a drop in government revenue in the case that nobody is worseoff. A possibility that a new system of gross and net wages could be established taking into account only $20 \%$ tax rate seems rather complicated and it has an uncertain outcome. In this case new rates of social security contributions would probably have to be set in order not to endanger the national health and pension insurance systems. It seems therefore easier to carry on the tax reform in a gradual established way. Namely, the accepted changes in tax codes already simplify the system as well as reduce tax burdens for entrepreneurships without putting in risk country's fiscal stability. Further tax reform should thus primarily reduce the taxation of labour i.e. the effective burden of social security contributions and reduce the highest $50 \%$ marginal tax rate of the income tax. In the same time accompanied measures such as gradual reduction of general government spending and improvement of other taxes (for example real estate tax), should be taken to keep the fiscal sustainability of the reform under control. 